\title{
Tumbuhan Obat di Zona Penyangga Taman Nasional Gunung Leuser Studi Kasus Desa Ketambe Kecamatan Ketambe Kabupaten Aceh Tenggara
}

\author{
(Potential of Medicinal plants in the Buffer Zone of Gunung Leuser National Park \\ Case Studies of Ketambe Village, Ketambe subdistrict, South East Aceh District)
}

\author{
Rahyumi Bahar', Iqbar', Ashabul Anhar ${ }^{1 *}$ \\ ${ }^{1}$ Program Studi Kehutanan PSDKU Unsyiah Gayo Lues, \\ Fakultas Pertanian, Universitas Syiah Kuala \\ *ashabul.anhar@unsyiah.ac.id
}

\begin{abstract}
Abstrak. Desa Ketambe merupakan salah satu desa yang berbatasan langsung dengan zona inti Taman Nasional Gunung Leuser (TNGL) dan berada dalam wilayah zona penyangga (buffer zone) TNGL. Hal ini menyebabkan adanya interaksi antara masyarakat Desa Ketambe dengan hutan di zona penyangga TNGL tersebut. Salah satu bentuk interaksi adalah pemanfaatan hasil hutan sebagai bahan obat. Namun data mengenai tumbuhan obat yang tumbuh di hutan tersebut belum seluruhnya terdokumentasi. Oleh karena itu perlu dilakukan inventarisasi tumbuhan obat dan pemanfaatannya oleh masyarakat Desa Ketambe di zona penyangga TNGL. Penelitian ini dilaksanakan pada bulan Juni sampai Juli 2019. Inventarisasi tumbuhan obat menggunakan metode kombinasi jalur dan garis berpetak dengan ukuran $20 \mathrm{~m}$ x $100 \mathrm{~m}$, sebanyak 10 jalur. Jenis tumbuhan obat dilakukan inventarisasi dari semua strata pertumbuhan mulai dari anakan, pancang, tiang dan pohon dengan petak contoh yang sesuai. Pengetahuan tentang pengobatan penyakit digali melalui wawancara dengan masyarakat di wilayah tersebut dengan metode keterlibatan masyarakat secara aktif (Participatory Rural Appraisal) yang dipilih secara sengaja (purposive sampling).Hasil analisis vegetasi diperoleh sebanyak 158 spesies dari 58 suku dan 70 spesies dari 38 suku $(44,30 \%)$ diantaranya merupakan tumbuhan yang dipergunakan untuk obat oleh masyarakat desa Ketambe. Tumbuhan suku Euphorbiaceae memiliki jumlah spesies terbanyak yang dapat dimanfaatkan untuk tumbuhan obat yaitu ada 9 spesies $(12,86 \%)$. Tumbuhan dari suku lainnya hanya dimanfaatkan untuk obat 3 hingga 1 spesies saja atau 4,29\% sampai 1,43\% dari total suku tumbuhan obat yang ditemukan di Desa Ketambe zona penyangga TNGL. Namun ada 7 spesies (10\%) tumbuhan obat yang belum mampu diidentifikasi temasuk bagian dari suku yang mana mereka tersebut. Ada 24 jenis penyakit yang diobati dengan berbagai tumbuhan obat di wilayah penelitian. Penyakit guna-guna merupakan penyakit yang dapat diobati dengan 21 spesies tumbuhan sehingga penyakit ini merupakan penyakit yang diobati dengan jumlah tumbuhan obat terbanyak. Bagian organ tumbuhan yang dipergunakan untuk pengobatan berbagai jenis penyakit berupa akar, batang, daun, bunga, kulit batang, duri, dan getah. Organ daun merupakan bagian tumbuhan yang paling dominan digunakan untuk mengobati berbagai macam jenis penyakit.
\end{abstract}

\section{Kata Kunci : Desa Ketambe, Tumbuhan Obat, Zona Penyangga TNGL}

Abstract. Ketambe Village is one of the villages directly adjacent to the core zone of Gunung Leuser National Park (TNGL) and within the buffer zone of TNGL. This caused an interaction between the people of Ketambe Village and the forest in the buffer zone of the TNGL. One form of interaction is the use of forest products as medicine. However, data on medicinal plants that grow in the forest are not yet fully documented. Therefore it is necessary to make an inventory of medicinal plants and their use by the people of Ketambe Village in the buffer zone of TNGL. This research was carried out in June to July 2019. Inventory of medicinal plants using a combination method of track and plotted lines with a size of $20 \mathrm{~m}$ x $100 \mathrm{~m}$, as many as 10 lines. Medicinal plant species are carried out an inventory of all growth strata starting from seedlings, saplings, poles and trees with suitable sample plots. Knowledge about the treatment of diseases was explored through interviews with communities in the area with the method of Participatory Rural Appraisal which was chosen deliberately (purposive sampling). The analysis of vegetation was obtained as many as 158 species from 58 families and 70 species from 38 families $(44,30 \%)$ of which are plants used for medicine by Ketambe villagers. Euphorbiaceae plants have the highest number of species that can be used for medicinal plants, there are 9 species $(12.86 \%)$. Plants from other families are only used for drugs of 3 to 1 species only or $4.29 \%$ to $1.43 \%$ of the total medicinal plant families found in Ketambe Village buffer zone of TNGL. However, there are 7 species (10\%) of medicinal plants which have not been able to be identified including the part of the families from which they are. There are 24 types of diseases that are treated with various medicinal plants in the study area. Witchcraft disease is a disease that can be treated with 21 species of plants so that this disease is a disease that is treated with the highest number of medicinal plants. Plant organ parts are used for the treatment of various types of diseases in the form 
of roots, stems, leaves, flowers, bark, thorns, and sap. Leaf organs are the most dominant part of plants used to treat various types of diseases.

Keywords: Ketambe Village, medicinal plants, TNGL Buffer zone

\section{PENDAHULUAN}

Pada umumnya masyarakat yang berbatasan langsung dengan hutan sangat bergantung terhadap sumberdaya alam hayati yang ada di sekitarnya. Daerah pedesaan di sekitar hutan sudah sejak dulu kala memanfaatkan tumbuhan untuk kehidupan sehari-hari berupa hasil hutan baik secara langsung maupun tidak langsung, seperti untuk kebutuhan pangan, perumahan, kesehatan, dll. Keadaan ini menyebabkan adanya interaksi antara masyarakat di sekitar kawasan hutan dengan potensi sumberdaya alam yang terdapat di dalamnya. Pemanfaatan sumberdaya alam untuk memenuhi kebutuhan kehidupan sehari-hari sebagai obat dan bahan obat merupakan budaya yang perlu digali dan menjadi pengetahuan yang sangat berharga agar pengetahuan tersebut tidak hilang seiring dengan perkembangan zaman.

Namun, perkembangan zaman yang semakin modern sekarang ini baik dari segi ilmu pengetahuan, teknologi dan pembangunan yang meningkatkan perekonomian masyarakat mengakibatkan menurunnya kearifan lokal dalam pemanfaatan sumberdaya alam khususnya tumbuhan obat oleh masyarakat di sekitar kawasan hutan. Tumbuhan obat secara alami tumbuh di berbagai kawasan hutan, demikian juga di sekitar kawasan hutan zona penyangga Taman Nasional Gunung Leuser (TNGL). Desa Ketambe berada di Kecamatan Ketambe, Kabupaten Aceh Tenggara merupakan salah satu desa yang berbatasan dengan TNGL dan berada dalam zona penyangga TNGL. Hasil wawancara singkat dengan tokoh masyarakat dan beberapa masyarakat Desa Ketambe diperoleh informasi masih sangat tinggi menggunakan tumbuhan baik di sekitar perumahan maupun yang berasal dari hutan untuk kebutuhan obatobatan. Oleh karena itu diperlukan penelitian untuk inventarisasi tumbuhan obat dan pemanfaatannya oleh masyarakat Desa Ketambe, di zona penyangga TNGL.

\section{Lokasi}

\section{METODE PENELITIAN}

Penelitian dilakukan di zona penyangga Taman Nasional Gunung Leuser (TNGL) yaitu di Desa Ketambe, Kecamatan Ketambe, Kabupaten Aceh Tenggara. Penelitian dilakukan dari bulan Juni sampai bulan Juli 2019.

\section{Alat, Bahan dan Objek Penelitian}

Alat yang digunakan dalam penelitian ini yaitu parang, patokan dari kayu, tali raffia, meteran, pita, alat tulis, kamera, sedangkan bahan yang digunakan adalah buku dendrologi dan buku terkait lainnya, kuesioner dan tally sheet. Objek penelitian adalah masyarakat Desa Ketambe yang menggunakan tumbuhan sebagai obat dan hutan zona penyangga TNGL di Desa Ketambe yang diduga memiliki tumbuhan obat.

\section{Tumbuhan Obat}

Tumbuhan obat didata dengan metode analisis vegetasi kombinasi jalur dan garis berpetak (transek) dengan ukuran $20 \mathrm{~m}$ x $100 \mathrm{~m}$, sebanyak 10 jalur. Data tumbuhan obat yang dikumpulkan meliputi nama spesies, jumlah individu setiap spesies untuk tingkat pertumbuhan semai, pancang, sedangkan untuk tingkat tiang dan pohon dicatat nama spesies, 
jumlah individu, diameter batang. Ukuran petak contoh untuk tingkat pertumbuhan semai dan tumbuhan bawah, $2 \mathrm{~m} \times 2 \mathrm{~m}$ (D), untuk tingkat pertumbuhan pancang $5 \mathrm{~m} \times 5 \mathrm{~m}$ (C), untuk tingkat pertumbuhan tiang $10 \mathrm{~m} \times 10 \mathrm{~m}(\mathrm{~B})$, dan untuk tingkat pertumbuhan pohon ukuran petaknya $20 \mathrm{~m}$ x $20 \mathrm{~m}$ (A) (Gambar 2).

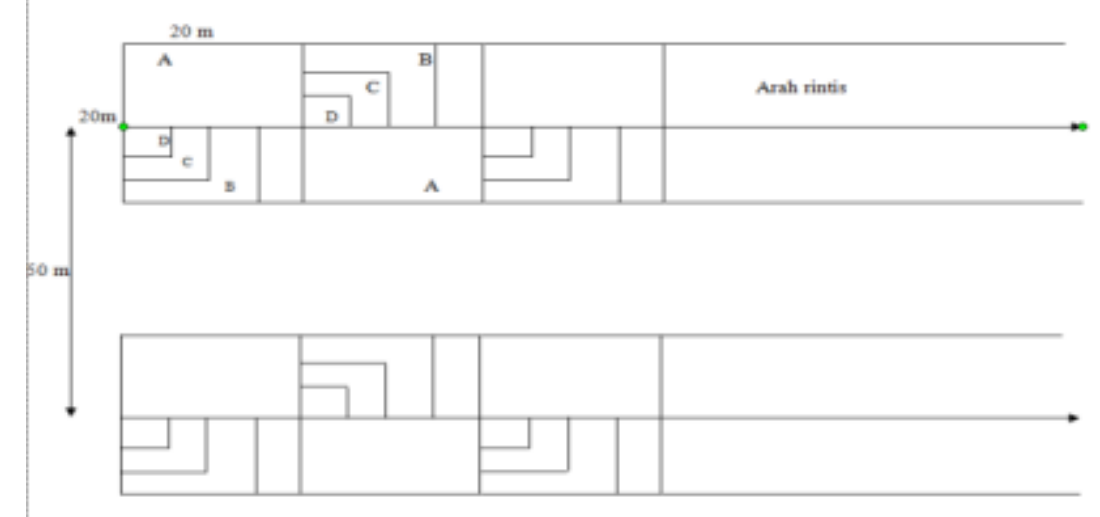

Gambar 1. Desain Petak Contoh di Lapangan dengan Metode Kombinasi (Kusmana, 1997)

\section{Pemanfaatan untuk Obat}

Pemanfaatan tumbuhan obat oleh masyarakat Desa Ketambe diperoleh dengan metode Participatory Rural Appraisal (PRA). Masyarakat dipilih secara purposive sampling yaitu dengan kriteria memiliki pengetahuan tentang tumbuhan obat diwawancara dan dilibatkan secara aktif dalam penelitian dengan cara menjawab pertanyaan sesuai kuesioner, menunjukkan tempat tumbuh tumbuhan obat tumbuh, mempraktekkan penggunaan tumbuhan sebagai obat, dan lain-lain.

\section{HASIL DAN PEMBAHASAN}

\section{Tumbuhan obat di zona penyangga TNGL}

Hasil analisis vegetasi ditemukan 158 (seratus lima puluh delapan) spesies di lokasi penelitan. Selanjutnnya dilakukan wawancara dengan masyarakat Desa Ketambe zona penyangga TNGL untuk mendapatkan data tumbuhan obat di kawasan tersebut. Hasil wawancara tersebut diperoleh data tumbuhan obat di zona pengangga TNGL seperti tercantum pada tabel 1 .

Tabel 1. Tumbuhan Obat di Desa Ketambe, Zona Penyangga TNGL

\begin{tabular}{llllc}
\hline No & \multicolumn{1}{c}{ Nama lokal } & \multicolumn{1}{c}{ Nama ilmiah } & Suku & Jumlah individu \\
\hline 1. & Aging bunga & Rinorea anguifera & Violaceae & 8 \\
2 & Akar iok ate & Mucuna sp. & Fabaceae & 2 \\
3 & Akar kekait & Uncaria sp. & Rubiaceae & 8 \\
4 & Akar kukut galang & Zizypus rufula & Rhamnaceae & 2 \\
5 & Akar labu imbo & Osoxyilum indicum & Bignoniaceae & 1 \\
6 & Akar lete & Tetrastigma & Vitaceae & 20 \\
7 & \multirow{2}{*}{ Akar mamul pola } & Chonemorpha & Apocynaceae & \\
& & microphylla & & 9
\end{tabular}




\begin{tabular}{|c|c|c|c|c|}
\hline No & Nama lokal & Nama ilmiah & Suku & Jumlah individu \\
\hline 8 & Akar merica & Mallotus philipensis & Euphorbiaceae & 11 \\
\hline 9 & Akar papan & Tetrastigma hookeri & Vitaceae & 2 \\
\hline 10 & Akar pelas & Tetracera acara & Dilleniaceae & 2 \\
\hline 11 & Akar rambut galang & Acacia pennata & Fabaceae & 3 \\
\hline 12 & Akar reriang & Cnetis platantha & Connaraceae & 5 \\
\hline 13 & Akar susu & Alyxia stellata & Apocynaceae & 5 \\
\hline 14 & Akar terujak & Averrhoa sp. & oxalidaceae & 1 \\
\hline 15 & Asam king & Dracontomelon dao & Anacardiaceae & 1 \\
\hline 16 & Asam peder & Orophea hexandra BI. & Annonaceae & 22 \\
\hline 17 & Balik putar & & & 4 \\
\hline 18 & Balik sumpah & Aglaia argentea & Meliaceae & 3 \\
\hline 19 & Bau langit & Cyathocalyx sumatranus & Annonaceae & 7 \\
\hline 20 & Bebahru & Hibiscus sp. & Malvaceae & 12 \\
\hline 21 & Bedarah & Knema sp. & Myristicaceae & 13 \\
\hline 22 & Bedarah lebar daun & Knema cinerea & Myristicaceae & 2 \\
\hline 23 & Bekar & & & 2 \\
\hline 24 & Belo ilang & Piper ornatum & Piperaceae & 2 \\
\hline 25 & Bemen & & & 3 \\
\hline 26 & Bergang piet & Baccaurea bracteata & Euphorbiaceae & 14 \\
\hline 27 & Bungur & Langerstroemia sp. & Lythraceae & 6 \\
\hline 28 & Cempaku & Fibraurea sp. & Menispermaceae & 5 \\
\hline 29 & Cempedak rawan & Arthocarpus sp. & Moraceae & 3 \\
\hline 30 & Dada kedih & Croton argyratus & Euphorbiaceae & 34 \\
\hline 31 & Enang-enang & & & 1 \\
\hline 32 & Jambu utan & Eugenia grandis & Myrtaceae & 18 \\
\hline 33 & Jerik jambu & Eugenia sp & Myrtaceae & 18 \\
\hline 34 & Kare & Averrhoa sp. & oxalidaceae & 1 \\
\hline 35 & Kayu alim & Aquilaria microcarpa & Thymelacaceae & 5 \\
\hline 36 & Kayu belo & Piper aduncum & Piperaceae & 1 \\
\hline 37 & Kayu dukut dasih & Planchonia vallida & Lecythydaceae & 2 \\
\hline 38 & Кауи етрап & Zantocylum aromatum & Rutaceae & 2 \\
\hline 39 & Kayu mayang & Payena lucida & Sapotaceae & 7 \\
\hline 40 & Kayu tiga urat & Cinnamomum javanicum & Lauraceae & 11 \\
\hline 41 & Kelumit & Litsea oppositifolia & Lauraceae & 10 \\
\hline 42 & Kembang soka & Ixora sp. & Rubiaceae & 6 \\
\hline 43 & Keminjin & Styrax benzoin & Styracaceae & 7 \\
\hline 44 & Kesebak & Garcinia sp. & Clusiaceae & 8 \\
\hline 45 & Kopi & Coffea arabica & Rubiaceae & 27 \\
\hline 46 & Kunyit uten & Curcuma zedoaria & Zingiberaceae & 12 \\
\hline 47 & Lange & Colocasia sp. & Araceae & 6 \\
\hline 48 & Lengen & Cananga odorata & Annonaceae & 3 \\
\hline 49 & Mangga uten & Mangifera sp. & Anacardiaceae & 2 \\
\hline 50 & Medang gatal & Litsea sp. & Lauraceae & 1 \\
\hline 51 & Medang licin & & & 1 \\
\hline 52 & Nibung & $\begin{array}{l}\text { Oncosperma } \\
\text { filamentosum }\end{array}$ & Arecaceae & 6 \\
\hline
\end{tabular}




\begin{tabular}{llllc}
\hline No & \multicolumn{1}{c}{ Nama lokal } & \multicolumn{1}{c}{ Nama ilmiah } & Suku & Jumlah individu \\
\hline 53 & Pakam & Pometia pinnata & Sapindaceae & 14 \\
54 & Pala hutan & Myristica sp. & Myristicaceae & 17 \\
55 & Pangang babi & Leea sp. & Leeaceae & 2 \\
56 & Pangguh & Arenga pinnata & Arecaceae & 1 \\
57 & Pepoa & Mallotus philipensis & Euphorbiaceae & 2 \\
58 & Peradah & Garcinia dioica & Guttiferaceae & 2 \\
59 & Percos & Elatior sp. & Zingiberaceae & 1 \\
60 & Rambe kekura & Byanaaccaurea motle & Euphorbiaceae & 31 \\
61 & Setur badak & Aglaia speciosa & Meliaceae & 15 \\
62 & Setur gajah & Aglaia odoratissima & Meliaceae & 2 \\
63 & Tampang & Blumeodendron tokbrai & Euphorbiaceae & 9 \\
64 & Tampu balik angin & Macaranga hypoleuca & Euphorbiaceae & 1 \\
65 & Tampu licin & Macaranga diepenhorstii & Euphorbiaceae & 3 \\
66 & Tampu tapak gajah & Macaranga triloba & Euphorbiaceae & 16 \\
67 & Tenggulun & Flacourtia rukun & Flacourtiaceae & 6 \\
68 & Terangon uten & & & 2 \\
69 & Tutup bumi & & & 4 \\
70 & Urel tenge & Cleidion spiciflorum & Euphorbiaceae & 7 \\
\hline
\end{tabular}

Tabel 1 di atas menunjukkan bahwa di Desa Ketambe zona penyangga TNGL ditemukan tujuh puluh (70) spesies tumbuhan obat dalam area cuplikan dengan total luas 1 hektar (ha). Hasil analisis vegetasi ditemukan tumbuhan yang paling tinggi populasinya adalah dada kedih (Croton argyratus) yaitu sebanyak 34 individu/ha. Dada kedih (Croton argyratus) adalah pohon yang termasuk ke dalam suku Euphorbiaceae, tinggi pohon dalam pertumbuhan maksimal mencapai 30 meter. Habitat asli spesies ini adalah hutan campuran dataran rendah. Selain jenis ini, rambe kekura (Byanaaccaurea motle) dari suku Euphorbiaceae juga merupakan jenis dengan populasi yang tinggi dengan jumlah individu dalam petak penelitian adalah 31 individu/ha. Spesies Croton argyratus dan Byanaaccaurea motle memiliki kemampuan beradaptasi secara baik dengan lingkungan tempat tumbuhnya, sehingga mampu tumbuh dan berkembang, serta bersaing dengan tumbuhan lainnya. Hal ini ditunjukkan dengan jumlah individunya yang lebih tinggi dibandingkan dengan jenis-jenis lainnya. Richard (1966), menyatakan tingkat penguasaan jenis dan komposisi jenis sangat berkaitan dengan persaingan pertumbuhan.

Tumbuhan obat yang didasarkan kepada suku/ family maka suku Euphorbiaceae memiliki jumlah spesies terbanyak yang dapat dimanfaatkan untuk tumbuhan obat yaitu ada 9 spesies $(12,86 \%)$ dari total spesies yang didapat dimanfaatkan untuk obat. Suku-suku lainnya hanya memiliki jumlah spesies yang dapat dimanfaatkan untuk obat adalah 3 hingga 1 spesies saja atau $4,29 \%$ sampai $1,43 \%$ dari total suku tumbuhan obat yang ditemukan di Desa Ketambe zona penyangga TNGL. Namun ada 7 spesies (10\%) tumbuhan obat yang belum mampu diidentifikasi temasuk bagian dari suku yang mana mereka tersebut.

Pada penelitian Nurhaida (2015) tentang tumbuhan obat di Dusun Kelampuk Kecamatan Tanah Pinoh Barat Kabupaten Melawi Kalimantan Barat ditemukan 3 spesies tumbuhan obat dari suku/family Euphorbiaceae. Data ini menunjukkan bahwa tumbuhan obat 
dari suku Euphorbiaceae di Desa Ketambe lebih banyak tiga kali lipat dari suku yang sama di tempat penelitian Nurhaida (2015). Namun data ini masih sangat kecil jika dibandingkan dengan data yang dilaporkan oleh Djawarningsih, (2007) yang mengatakan bahwa terdapat 148 jenis tumbuhan dari suku Euphorbiaceae telah dimanfaatkan sebagai obat. Jumlah spesies dari suku Euphorbiaceae lebih dominan menjadi tumbuhan obat karena jumlahnya di alam yang berlimpah. Hal ini diduga sangat erat kaitannya dengan sistem pemencaran buah maupun biji yang cukup baik serta memiliki kemampuan yang tinggi untuk beradaptasi pada berbagai kondisi lingkungan. Banyak anggota jenis Euphorbiaceae baik bentuk pohon, pohon kecil maupun perdu dikenal sebagai tumbuhan jenis hutan sekunder yang tumbuh dan beradaptasi pada daerah bekas perladangan, semak belukar, hutan primer terutama daerah bukaan kanopi (rumpang) (Lammertink, 2004). Pemencaran buah atau biji jenis-jenis Euphorbiaceae umumnya dilakukan oleh burung dan mamalia (Partomihardjo et al., 1999).

\section{Pengobatan Penyakit}

Jenis-jenis penyakit yang diobati dari 70 (tujuh puluh) spesies tumbuhan obat di Zona Penyangga TNGL, desa Ketambe adalah 24 jenis penyakit. Jenis penyakit guna-guna dapat diobati dengan 21 (dua puluh satu) spesies tumbuhan obat dan merupakan jenis penyakit yang paling banyak dapat diobati dengan berbagai spesies tumbuhan. Penyakit ini diobati dengan menggunakan bagian organ yang berbeda-beda dari setiap spesies tumbuhan tersebut mulai dari akar, batang, daun, bunga, kulit batang, duri, dan getah. Organ daun paling dominan digunakan untuk mengobati penyakit guna-guna. Diare merupakan jenis penyakit yang dapat diobati dengan 6 (enam) spesies tumbuhan dengan menggunakan bagian akar, batang, daun dan kulit buah. Kulit buah merupakan bagian tumbuhan yang paling dominan digunakan untuk mengobati diare. Bagian kulit buah ada yang mengandung senyawa astrigen yang dapat digunakan sebagai obat diare. Penyakit demam juga dapat diobati dengan 6 (enam) spesies tumbuhan dengan menggunakan organ daun yang paling dominan, sedangkan organ lain yang dapat dimanfaatkan untuk pengobatan penyakit ini adalah buah, kulit batang, dan umbi. Penyakit keracunan dapat digunakan 5 (lima) spesies tumbuhan dengan menggunakan buah sebagai organ yang dominan untuk pengobatan tersebur. Penggunaan organ lain dalam dengan frekuensi yang rendah adalah organ daun. Organ lainnya dari tumbuhan tidak pernah digunakan untuk mengobati penyakit keracunan. Sakit perut dan disentri dapat diobati dengan 8 (delapan) spesies tumbuhan dengan penggunaan organ buah yang lebih dominan. Organ lain yang dipergunakan untuk mengobati sakit perut dan disentri adalah daun, dan kulit batang. Kudis dan gatal yang disebabkan oleh ulat bulu dapat diobati dengan 4 (empat) spesies tumbuhan. Organ tumbuhan yang digunakan untuk pengobatan penyakit ini adalah daun, getah, batang dan buah. Ada satu spesies tumbuhan dengan nama lokan kare (belum mampu diidentifikasi) dapat digunakan untuk mengobati penyakit kanker payudara dan jenis tumor lainnya termasuk untuk mengobati bisul. Bagian tumbuhan yang digunakan untuk pengobatan penyakit ini adalah bagian batang yang masih muda. Informasi detil terkait dengan spesies tumbuhan, bagian yang digunakan untuk mengobati penyakit dan khasiat untuk mengobati jenis penyakit ditampilkan pada tabel 2 . 
Tabel 2. Jenis Tumbuhan Obat, Bagian Tumbuhan, dan Khasiat Obat di Zona Penyangga TNGL

\begin{tabular}{|c|c|c|c|c|}
\hline No & Nama lokal & Nama ilmiah & Bagian yang digunakan & Khasiat \\
\hline & Aging bunga & Rinorea anguifera & Akar & Diare \\
\hline 2. & Akar iok ate & Mucuna sp. & Daun & Kudis \\
\hline & Akar kekait & Uncaria sp. & Duri, Kulit batang & $\begin{array}{l}\text { Guna-guna, } \\
\text { Disentri }\end{array}$ \\
\hline & Akar kukut kalang & Zizypus rufula & Duri & Guna-guna \\
\hline 5. & Akar labu imbo & Osoxyilum indicum & Akar, batang & $\begin{array}{l}\text { Penawar racun, } \\
\text { kudis }\end{array}$ \\
\hline & Akar lete & $\begin{array}{l}\text { Tetrastigma } \\
\text { lanceolarium }\end{array}$ & Daun & Demam \\
\hline & Akar mamul pola & $\begin{array}{l}\text { Chonemorpha } \\
\text { microphylla }\end{array}$ & Akar & Guna-guna \\
\hline & Akar merica & Piper albi Linn. & Akar & Guna-guna \\
\hline & Akar papan & Tetrastigma hookeri & Daun & Demam \\
\hline 10. & Akar pelas & Tetracera acara & Batang & Diare \\
\hline 11. & Akar rambut galang & Acacia pennata & Buah, duri & $\begin{array}{l}\text { Anti ketombe, } \\
\text { guna-guna }\end{array}$ \\
\hline 12. & Akar reriang & Cnetis platantha & Daun & Demam \\
\hline 13. & Akar susu & Alyxia stellata & Daun & Disentri \\
\hline 14. & Akar terujak & Averrhoa sp. & Buah & Sakit perut \\
\hline 15. & Asam king & Dracontomelon dao & Buah & Penawar racun \\
\hline 16. & Asam peder & Orophea hexandra BI. & Buah & Penawar racun \\
\hline 17. & Balik putar & & Daun, batang, kulit batang & Guna-guna \\
\hline 18. & Balik sumpah & Aglaia argentea & Daun & Guna-guna \\
\hline 19. & Bau langit & $\begin{array}{l}\text { Cyathocalyx } \\
\text { sumatranus }\end{array}$ & Daun & Terluka \\
\hline 20. & Bebahru & Hibiscus sp. & Buah & Penawar racun \\
\hline 21. & Bedarah & Knema sp. & Biji & Terkilir \\
\hline 22. & Bedarah lebar daun & Knema cinerea & Biji & Terkilir \\
\hline 23. & Bekar & & Buah & Terkena ulat bulu \\
\hline 24. & Belo ilang & Piper ornatum & Daun & Batuk \\
\hline 25. & Bemen & & Buah & Bisul \\
\hline 26. & Bungur & Langerstroemia sp. & Duri & Guna-guna \\
\hline 27. & Cempaku & Fibraurea sp. & Akar & Sakit perut \\
\hline 28. & Cempedak rawan & Arthocarpus sp. & Kulit batang & Diare \\
\hline 29. & Dada kedih & Croton argyratus & Daun & Guna-guna \\
\hline 30. & Enang-enang & & Daun & Guna-guna \\
\hline 31. & Jambu uten & Eugenia grandis & Kulit batang & $\begin{array}{l}\text { Sakit perut, jamu- } \\
\text { jamuan }\end{array}$ \\
\hline 32. & Jerikjambu & Eugenia sp & Kulit batang & $\begin{array}{l}\text { Sakit perut, jamu- } \\
\text { jamuan }\end{array}$ \\
\hline 33. & Kare & & Batang muda & $\begin{array}{l}\text { Tumor payudara, } \\
\text { bisul }\end{array}$ \\
\hline 34. & Kaуи alim & Aquilaria malacensis & Kulit batang & Guna-guna \\
\hline
\end{tabular}




\begin{tabular}{|c|c|c|c|c|}
\hline No & Nama lokal & Nama ilmiah & Bagian yang digunakan & Khasiat \\
\hline 35. & Kayи belo & Piper aduncum & Daun & Guna-guna \\
\hline 36. & Kayu dukut dasih & Planchonia valida & Buah & Disentri \\
\hline 37. & Kayи eтpan & Zantocylum aromatum & Buah & $\begin{array}{l}\text { Sakit badan/sendi, } \\
\text { masuk angin }\end{array}$ \\
\hline 38. & Kayu mayang & Payena lucida & Buah & Disentri \\
\hline 39. & Kayu tiga urat & Cinnamomum sp. & Daun & Guna-guna \\
\hline 40. & Kelumit & Litsea oppositifolia & Daun & Diare \\
\hline 41. & Kembang soka & & Bunga & Guna-guna \\
\hline 42. & Keminjin & Styrax benzoin & Getah & $\begin{array}{l}\text { Guna-guna, sakit } \\
\text { perut }\end{array}$ \\
\hline 43. & Kesebak & Garcinia sp. & Buah & Sakit perut \\
\hline 44. & Kopi & Coffea Arabica & Daun tua, biji & $\begin{array}{l}\text { Sakit } \\
\text { kepala/migran }\end{array}$ \\
\hline 45. & Kunyit uten & Curcuma zedoaria & Umbi, rimpang & $\begin{array}{l}\text { Jamu } \\
\text { melahirkan }\end{array}$ \\
\hline & $\begin{array}{l}\text { Lange } \\
\text { Lengen }\end{array}$ & $\begin{array}{l}\text { Colocasia sp. } \\
\text { Cananga odorata }\end{array}$ & $\begin{array}{l}\text { Batang } \\
\text { Bunga }\end{array}$ & $\begin{array}{l}\text { Terkena ulat bulu } \\
\text { Guna-guna }\end{array}$ \\
\hline 48. & Mangga uten & Mangifera sp. & Kulit batang & Diare \\
\hline 49. & Medang gatal & Litsea sp. & Kulit batang & Anti Nyamuk \\
\hline 50. & Medang licin & & Buah & Demam \\
\hline 51. & Nibung & $\begin{array}{l}\text { Oncosperma } \\
\text { filamentosum }\end{array}$ & Batang & $\begin{array}{l}\text { Pennyakit guna- } \\
\text { guna }\end{array}$ \\
\hline 52. & Pakam & Pometia pinnata & Kulit batang & Sakit perut \\
\hline 53. & Pala uten & Myristica sp. & Biji & $\begin{array}{l}\text { Terluka } \\
\text { terkilir }\end{array}$ \\
\hline 54. & Panggang babi & Leea sp. & Kulit batang & Demam \\
\hline 55. & Pangguh & Arenga pinata & Daun, air batang & Cacar api \\
\hline 56. & Pepoa uten & Mallotus philipensis & Daun & Ginjal \\
\hline 57. & Peradah & Garcinia dioica & Buah & Penawar racun \\
\hline 58. & Percos & Elatior sp. & Umbi & Demam \\
\hline 59. & Rambe kekura & Byanaaccaurea motle & Kulit batang & Diare \\
\hline 60. & Setur badak & Aglaia speciosa & Getah & Guna-guna \\
\hline 61. & Setur gajah & Aglaia odoratissima & Daun & Asma \\
\hline & Soyo & & Duri & Guna-guna \\
\hline 63. & Tampang & Blumeodendron tokbrai & Daun & Guna-guna \\
\hline 64. & Tampu balik angin & Macaranga hypoleuca & Daun & Guna-guna \\
\hline 65. & Tатри licin & $\begin{array}{l}\text { Macaranga } \\
\text { diepenhorstii }\end{array}$ & Getah & Kudis \\
\hline 66. & Tampu tapak gajah & Macaranga triloba & Getah & Tersengat binatang \\
\hline 67. & Tenggulun & Flacourtia rukun & Duri & Guna-guna \\
\hline 68. & Terangon uten & & Daun & Jamu-jamuan \\
\hline & Tutup bumi & & Daun & Guna-guna \\
\hline 70. & Urel tenge & Mallotus sp. & Daun & Penawar racun \\
\hline
\end{tabular}




\section{Organ Tumbuhan untuk Pengobatan Penyakit}

Berdasarkan data spesies yang ditemukan, terdapat beberapa bagian potensi tumbuhan obat yang berkasiat sebagai obat. Masing-masing spesies memiliki keunikan bagian yang dimanfaatkan. Beberapa spesies terdapat lebih dari satu bagian yang dapat dimanfaatkan. Data mengenai persentase bagian yang digunaan disajikan pada Gambar 2.

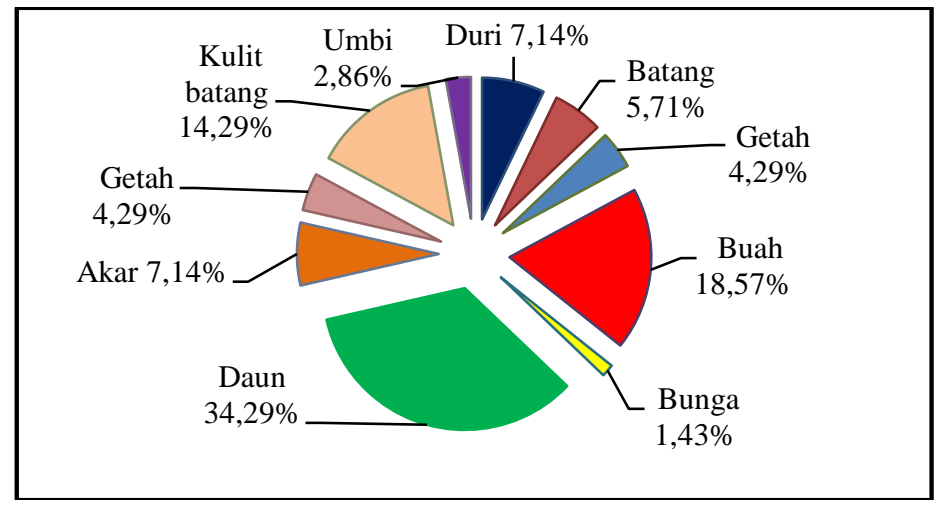

Gambar 2. Persentase Bagian untuk Pengobatan Penyakit

Bagian tumbuhan yang paling sering digunakan dan banyak dimanfaatkan adalah daun, yaitu sebanyak 34,29\%. Keadaan ini dapat disebabkan karena bagian daun merupakan bagian yang selalu tersedia dan sangat mudah dijumpai, pemanfaatannya dan pengambilannya termasuk sederhana dan mudah. Selain itu kemungkinan lain karena kegunaan daun diketahui secara turun temurun lebih banyak dalam segi penyembuhannya dibandingkan dengan bagian lainnya Penggunaan bagian tumbuhan sebagai obat tidak hanya menggunakan organ daun tetapi juga batang, akar, kulit batang tetapi penggunaannya harus dibatasi karena dapat menyebabkan kematian pada tumbuhan tersebut. Menurut Hasanah (2011), mengatakan bahwa pemanfaatan pada bagian daun tidak terlalu menjadi masalah bagi kerusakan hutan sehingga memiliki potensi pengelolaan secara lestari yang baik, karena daun merupakan bagian tumbuhan yang dapat beregenerasi dengan cepat. Berbeda halnya dengan bagian yang digunakan bagian batang, kulit batang, akar, dan rimpang, hal ini akan merusak tumbuhan secara langsung dan berdampak terhadap kelestarian spesies tumbuhan dalam kawasan hutan tersebut

\section{KESIMPULAN}

Kekayaan tumbuhan pada lokasi penelitan adalah 158 spesies dan 70 spesies $(49,30 \%)$ dari 38 suku/family merupakan tumbuhan obat. Penggunaan tumbuhan obat di zona penyangga TNGL dapat mengobati 24 jenis penyakit dengan menggunakan berbagai organ dan bagian lain dari tumbuhan dengan penggunaan bagian dominan adalah daun, buah dan kulit batang.

\section{DAFTAR PUSTAKA}

Djawarningsih T. 2007. Jenis-jenis Euphorbiaceae (jarak-jarakan) yang Berpotensi sebagai Obat Tradisional. Puslit Biologi-LIPI. Cibinong. 
Hasanah N. 2011. Potensi Tumbuhan Berguna di Cagar Alam Yanlappa, Bogor-Jawa Barat: Departemen Konservasi Sumberdaya Hutan dan Ekowisata, Fakultas Kehutanan Institut Pertanian Bogor.

Kusmana C, Istomo. 1995. Ekologi Hutan. Bogor: Fakultas Kehutanan. Institut Pertanian Bogor.

Nurhaida. 2015. Studi Etnobotani Tumbuhan Obat di Dusun Kelampuk Kecamatan Tanah Pinoh Barat Kabupaten Melawi. Fakultas Kehutanan, Universitas Tanjungpura. Pontianak.

Partomihardjo T, Syahirsyah, Albertus dan Soedjito H, 1999. Flora Pohon dan Tipe Hutan Taman Nasional Bentuang Karimun Kalimantan Barat. Prosiding RPTN Bentuang Kaimun.

Richards, P. W. 1966. The Tropical rain Forest and Ecological Study. Institut Pertanian Bogor. 